\title{
Tinjauan Kemampuan A wal Matematis dalam Kemampuan Pemecahan Masalah pada Pembelajaran Berbasis Masalah Melalui Menulis Matematika
}

\author{
Riki Andriatna \\ Universitas Sebelas Maret \\ andriatna.riki@staff.uns.ac.id
}

Diterima: Maret 2020. Disetujui: Maret 2020. Dipublika sikan: Juli 2020.

\begin{abstract}
ABSTRAK
Penelitian ini bertujuan untuk melihat pengaruh model pembelajaran berbasis masalah yang dikombinasikan dengan menulis matematika terhadap kemampuan pemecahan masalah dengan tinjauan kemampuan awal matematis siswa dengan kategori tinggi, sedang, dan rendah. Penelitian ini merupakan penelitian kuasi eksperimen dengan menggunakan satu kelompok eksperimen dengan perlakukan model pembelajarann berbasis masalah yang dikombinasikan dengan menulis matematika dan satu kelompok kontrol yang hanya diberikan perlakukan model pembelajaran berbasis masalah. Metode pengumpulan data terdiri dari tes kemampuan pemecahan masalah matematis. Teknik analisis data menggunakan analisis variansi dua jalan sel tidak sama. Hasil penelitian menunjukkanbahwa kemampuan pemecahan masalah siswa yang menggunakan model pembelajaran berbasis masa lah yang dikombina sikan dengan menulis matematika lebih baik daripada kemampuan pemecahan masalah siswa yang hanya menggunakan model pembelajaran berbasis masalah secara umum maupun berdasarkan kategori kemampuan awal matematis. Ditinjau dari kategori kemampuan awal matematis, siswa kategori tinggi dan sedang menunjukkan tidak a danya perbedaan kemampuan pemecahan masalah yang signifikan, sedangkan kemampuan pemecahan masalah siswa kategori tinggi dan sedang lebih baik jika dibandingkan dengan kemampuan pemecahan masalah siswa kategori rendah.

Kata kunci: pembelajaran berbasis masalah, menulis matematika, kemampuan pemecahan masalah, kemampuan a wal matematis.
\end{abstract}

\begin{abstract}
This study aims to look at the effect of problem-based learning models combined with mathematical writing on problem solving abilities with a review of students' mathematical early capabilities in high, medium, and low categories. This research is a quasi-experimental study using one experimental group with the treatment of problem-based learning models combined with writing mathematics and a control group that is only given the treatment of problem-based learning models. Data collection methods consist of tests of mathematical problem solving abilities. Data analysis techniques using two path analysis of variance are not the sam cell. The results showed that the problem-solving ability of students who use problem-based learning models combined with writing mathematics is better than the problem-solving abilities of students who only use problem-based learning models in general or by the category of mathematical early ability. Judging from the early mathematical a bility category, high and medium category students showed no significant difference in problem solving abilities while the problem solving ability of high and medium category students was better when compared to the problem solving ability of low category students.
\end{abstract}

Keywords: problem based learning, writing mathematics, problem solving ability, mathematics early ability.

How to Cite: Andriatna, R. (2020). Tinjauan Kemampuan Awal Matematis dalam Kemampuan Pemecahan Masalah pada Pembelajaran Berbasis Masalah Melalui Menulis Matematika.Journal of Medives: Journal of Mathematics Education IKIP Veteran Semarang , 4(2), 285-294. 


\section{PENDAHULUAN}

Pembelajaran matematika seba-gai salah satu implementasi tujuan pendidikan Indonesia turut andil dalam proses pembangunan sumber daya manusia Indonesia. Era revolusi industri 4.0 yang dihadapi pada masa sekarang menimbulkan permasalahan yang semakin kompleks. Akibatnya, proses pendidikan, khususnya dalam proses pembelajaran, haruslah bisa menjawab segala tantangan yang hadir. Sejalan dengan hal tersebut, pembelajaran matematika harus mengalami tranformasi, tidak hanya memahamkan konsep semata, tetapi penerapan konsep atau ide dalam penyelesaian permasalahan kehidupan. NCTM (2000) menyatakan bahwa salah satu standar proses dalam pembelajaran matematika adalah berkenaan dengan pembelajaran yang mengandung pemecahan masalah. Dalam rangka mewujudkan tujuan pembelajaran matematika tersebut, seorang guru haruslah membiasakan pembelajaran dengan menghadirkan situasi-situasi pembelajaran berupa masalah-masalah yang mendorong peserta didik untuk ikut serta memecahkannya. Ini menunjukkan bahwa salah satu cara untuk memahami konsep dan ide matematika dapat didasarkan pada pemecahan masalah, khususnya masalah non-rutin (Saragih et al., 2017).

Situasi-situasi pembelajaran, seperti soal-soal matematika yang digunakan dalam pembelajaran haruslah merupakan suatu masalah, sehingga siswa terbiasa untuk memecahkan masalah. Meika dan Sujana (2017) menyatakan bahwa masalah adalah sesautu yang belum diketahui penyelesaiannya, sehingga memecahkan masalah berarti mencari penyelesaian dari sesuatu yang belum diketahui penyelesaiannya. Ini berarti jika siswa sudah memiliki strategi untuk menyelesaikan situasi tersebut, maka situasi tersebut dapat dianggap hanya sebagai latihan (Schoenfeld, 1987). Sehingga Foshay dan Kirkley (1998) menyatakan bahwa situasi atau permasalahan yang dapat disajikan dalam pembelajaran matematika dapat berasal dari kehidupan nyata yang disajikan dalam bentuk model matematika. Dengan adaanya situasi-situasi yang berasal dari konteks kehidupan nyata, Hudojo (2003) menjelaskan bahwa pembelajaran matematika tersebut dapat memfasilitasi kemampuan pemecahan masalah, karena siswa melakukan analisis dan berpikir kritis sehingga dihasilkan suatu keputusan. Kemampuan dalam mengambil keputusan untuk menyelesaian situasi masalah tersebut merupakan suatu kemampuan yang sangat berguna dalam kehidupannya kelak.

Polya (Andriatna, 2015; Wahyuningtyas et al., 2020) menyatakan bahwa kemampuan pemecahahan masalah merupakan kemampuan siswa untuk memahami masalah, menyusun strategi pemecahan, melaksanakan startegi pemecahan, dan melihat kembali penyelesaian untuk menentukan kesesuaian solusi dengan permasalahan. Foshay dan Kirkley (1998) menyatakan bahwa kemampuan pemecahan masalah melibatkan komponen kognitif yang kompleks. Hal ini menyebabkan kemampuan pemecahan masalah melibatkan tahapan proses yang menghubungkan pengalaman siswa yang telah lampau 
dengan permasalahan yang sedang dihadapi untuk kemudian dicarikan penyelesaian-penyelesaian yang dapat digunakan untuk memecahkan permasalahan (Gick \& Holyoak, 1980; Mayer, 1983; Schoenfeld, 1980). Hal inilah yang menjadikan kemampuan pemecahan masalah merupakan salah satu kemampuan tingkat tinggi yang sangat penting sehingga NCTM (2000) menjadikan kemampuan pemecahan masalah sebagai fokus dalam pembelajaran matematika. Dengan adanya tujuan tersebut, diharapkan kemampuan yang terbentuk dari proses pembelajaran tersebut menjadi sangat bermakna (Pinter, 2012), tidak terkecuali untuk siswa SMA.

Meskipun demikian, pembelajaran matematika dianggap sebagai sesuatu yang tidak menyenangkan bagi sebagian siswa (Simamora et al., 2019), sehingga memberikan dampak negatif terhadap kemampuan matematis siswa, salah satunya kemampuan pemecahan masalah matematis. Di sisi lain, kurangnya peran guru dalam menyajikan persoalanpersoalan non-rutin dalam pembelajaran matematika turut serta memperlemah kemampuan pemecahan masalah matematis. Penelitian menunjukkan bahwa kemampuan pemecahan masalah matematis siswa masih rendah (Amalia dalam Andriatna, 2015; Nidya et al., 2015; Simamora et al., 2019). Hasil penelitian TIMSS 2011 menempatkan Indonesia pada peringkat ke-36 dari 40 dengan sebanyak $43 \%$ siswa masih berada pada low benchmark, $15 \%$ intermediate benchmark, $2 \%$ high benchmark, dan $0 \%$ advance benchmark dengan keseluruhan skor rata-rata 386 jauh di bawah negara Thailand (427) dan Malaysia (440)
(Mullis et al., 2012). Hal tersebut mengindikasikan bahwa siswa bisa jadi hanya menghafal konsep dan tidak mampu menerapkannya dalam memecahkan permasalahan yang dihadapi (Trianto, 2009).

Rendahnya kemampuan pemecahan masalah dapat disebabkan berbagai faktor, salah satunya berasal dari proses pembelajaran yang dilakukan di dalam kelas. Turmudi (2012) menjelaskan bahwa proses pembelajaran matematika yang terjadi sebagian besar menekankan pada proses chalk and talk, dimana guru menjelasankan rumus, siswa mencatat rumus, dan pemberian soal tanpa adanya pemaknaan terhadap konsep. Dengan tidak adanya pemaknaan terhadap konsep matematika, siswa mengalami kesulitan ketika menghadapi permasalahan-permasalahan non rutin, karena siswa tidak menemukan bentuk yang serupa dengan contoh soal yang diberikan oleh guru. Kondisi tersebut menggambarkan perlunya suatu inovasi pembelajaran yang lebih variasi, khususnya untuk membantu siswa dalam meningkatkan kemampuan pemecahan masalah. Salah satu inovasi pembelajaran yang ditawarkan dalam penelitian ini adalah melalui model pembelajaran berbasis masalah yang dikombinasikan dengan metode menulis matematika.

Model pembelajaran berbasis masalah merupakan model pembelajaran yang berpusat pada siswa dengan masalah sebagai awal pembelajaran sehingga siswa terfasilitasi untuk melakukan kegiatan memecahkan masalah sehingga dapat mengembangkan kemampuan pemecahan masalah (Barrows \& Kelson, 1995; Hmelo-Silver, 2004). 
Pembelajaran berbasis masalah menjadikan siswa aktif dalam proses pembelajaran karena situasi pembelajaran yang disajikan berupa permasalahan, yaitu permasalahan nyata, sehingga siswa dapat menyusun strategi dan membangun pengetahuannya (Hmelo-Silver \& Ferrari, 1997; Kolodner et al., 1996). Savery (2006) menyatakan bahwa permasalahan yang harus disusun oleh guru sebagai fasilitator dalam pembelajaran berbasis masalah adalah permasalahan yang tidak lengkap (ill-structured) sehingga siswa memiliki kebebasan dalam mencari dan menemukan solusi atas permasalahan tersebut. Hal ini memberikan tantangan tersendiri kepada guru mengenai bagaimana guru menyajikan permasalahan tidak lengkap, tetapi dapat memberikan pemahaman konsep yang utuh kepada siswa.

Selain itu, untuk menguatkan pemahaman siswa, selama proses pembelajaran, model pembelajaran dikombinasikan dengan metode menulis matematika. Idris (2009) menyatakan bahwa menulis matematika memunculkan kegiatan eksplorasi, justifikasi, diskusi, investigasi, dan memperdiksi sehingga memunculkan proses kreatif. Kegiatan-kegiatan tersebut menurut Idris (2009) muncul karena siswa menguraikan masing-masing langkah yang akan digunakan dalam menyelesaikan masalah, menjelaskan alasan penggunaan langkah tersebut, dan menunjukkan bagaimana mereka menggunakan pengetahuan sebelumnya dalam menyelesaikan masalah. Hal ini sejalan dengan kegiatan pembelajaran berbasis masalah, dimana pada pembelajaran tersebut siswa dituntut untuk bereksplorasi dan melakukan investigasi untuk memecahkan permasalahan.

Siswa SMA, secara tingkatan sekolah, sudah memiliki pengetahuan daar matematika yang relevan dengan yang akan diterima. Pinker (Marhami, 2016) menyatakan bahwa hadirnya siswa di kelas membawa sejumlah pengetahuan sebelumnya yang didasarkan pada pengalaman mereka. Hal ini sejalan dengan teori belajar Ausubel (Dahar, 2006) bahwa pembelajaran merupakan kegiatan yang menghubungkan pengetahuan baru dengan pengetahuan sebelumnya sehingga menjadi bermakna. Ini mengindikasikan bahwa kemampuan awal sangat penting dalam proses pembelajaran, dimana kemampuan tersebut bukan merupakan bawaan sejak lahir melainkan dipengaruhi lingkungan (Ruseffendi, 2010). Dengan demikian, selain bertujuan untuk mengetahui pengaruh model pembelajaran berbasis masalah yang dikombinasikan dengan menulis matematika terhadap kemampuan pemecahan masalah, juga akan meninjau aspek kemampuan awal matematis (KAM) siswa.

\section{METODE PENELITIAN}

Penelitian ini merupakan penelitian kuasi eksperimen dengan kelompok eksperimen menggunakan pembelajaran menggunakan model pembelajaran berbasis masalah yang dikombinasikan dengan menulis matematika dan kelompok kontrol menggunakan pembelajaran berbasis masalah tanpa menulis matematika. Populasi pada penelitian ini adalah seluruh siswa Kelas X IPA dari suatu sekolah di Kota Bandung dengan sampel kelas X IPA 4 sebagai kelompok eksperi- 
men dan X IPA 2 sebagai kelas kontrol masing-masing berukuran 31 orang. Analisis data dilakukan terhadap data kuantitatif berupa hasil tes pemecahan masalah matematis menggunakan analisis variansi (Anava) dua jalan dengan efek utama adalah KAM (faktor baris) dan kelompok (faktor kolom) dengan terlebih dahulu melakukan uji normalitas dan homogenitas.

\section{HASIL DAN PEMBAHASAN}

Analisis data kuantitatif tes akhir kemampuan pemecahan masalah dilakukan dengan melakukan pengelompokan data siswa berdasarkan KAM dengan sebaran siswa seperti pada Tabel 1. Selanjutnya dilakukan analisis deskriptif terhadap data tes akhir kemampuan pemecahan masalah matematis untuk kelompok eksperimen dan kontrol ditinjau dari kemampuan awal matematika (KAM) yang hasilnya dapat dilihat pada Tabel 2.

\begin{tabular}{lccc}
\multicolumn{4}{c}{ Tabel 1. Sebaran Siswa berdasar KAM } \\
\hline KAM & Eksperimen & Kontrol & Total \\
\hline Tinggi & 4 & 7 & 11 \\
Sedang & 22 & 18 & 40 \\
Rendah & 5 & 6 & 11 \\
Total & 31 & 31 & 62 \\
\hline
\end{tabular}

Tabel 2. Nilai Rerata Tes Akhir

\begin{tabular}{lccc}
\hline \multicolumn{1}{c}{ KAM } & $\begin{array}{c}\text { Eksperi- } \\
\text { men }\end{array}$ & Kontrol & $\begin{array}{c}\text { Rerata } \\
\text { Marginal }\end{array}$ \\
\hline Tinggi & 39,50 & 30,00 & 33,45 \\
Sedang & 36,55 & 24,44 & 31,10 \\
Rendah & 21,60 & 17,33 & 19,27 \\
Rerata Marginal & 34,52 & 24,32 & - \\
\hline
\end{tabular}

Berdasarkan Tabel 2 dapat dilihat bahwa nilai rerata kelompok eksperimen lebih dari nilai rerata kelompok kontrol, sehingga diduga bahwa kemampuan pemecahahan masalah matematis kelompok eksperimen lebih baik daripada kemampuan pemecahan masalah matematis kelompok kontrol. Ditinjau dari KAM, nilai rerata siswa dengan KAM tinggi lebih besar dari pada nilai rerata siswa dengan KAM sedang dan rendah dan nilai rerata siswa KAM sedang lebih besar daripada nilai rerata siswa dengan KAM rendah. Berdasarkan nilai rerata untuk KAM tersebut, diduga bahwa kemampuan pemecahan masalah matematis siswa KAM tinggi lebih baik daripada kemampuan pemecahan siswa KAM sedang dan siswa KAM rendah serta kemampuan pemecahan masalah siswa KAM sedang lebih baik daripada kemampuan pemecahan masalah siswa KAM rendah. Untuk menguji signifikansi dugaan tersebut, dilakukan Anava dua jalan dengan sel tidak sama dengan terlebih dahulu dilakukan uji normalitas dan homogenitas.

Hasil uji normalitas pada Tabel 3 menggunakan uji Kolmogorov-Smirnov dengan bantuan software SPSS 21 untuk faktor kolom, yaitu data kelompok eksperimen dan kontrol, dan faktor baris, yaitu data KAM tinggi, KAM sedang, dan KAM rendah, keseluruhannya berasal dari populasi berdistribusi normal. Serupa dengan pengujian normalitas, uji homogenitas pada Tabel 4 menunjukkan bahwa populasi memiliki varians yang sama (homogen).

Tabel 3. Uji Normalitas

\begin{tabular}{lccc}
\hline \multicolumn{1}{c}{ Kelompok } & Statistik & $\mathrm{dk}$ & Sig. \\
\hline Eksperimen & 0,13 & 31 & 0,19 \\
Kontrol & 0,12 & 31 & 0,20 \\
KAM Tinggi & 0,25 & 11 & 0,05 \\
KAM Sedang & 0,12 & 40 & 0,18 \\
KAM Rendah & 0,13 & 11 & 0,20 \\
\hline
\end{tabular}


Tabel 4. Uji Homogenitas

\begin{tabular}{ccccc}
\hline Sumber & Uji Levene & dk1 & dk2 & Sig. \\
\hline KAM & 1,49 & 2 & 59 & 0,23 \\
Model & 0,35 & 1 & 60 & 0,56 \\
\hline
\end{tabular}

Hasil pengujian hipotesis menggunakan Anava dua jalan dengan sel tidak sama dengan bantuan software SPSS 21 diperlihatkan pada Tabel 5.

Tabel 5. Analisis Variansi Dua Jalan

\begin{tabular}{ccccc}
\hline Sumber & dk & RK & F & Sig. \\
\hline KAM & 2 & 706,74 & 7,83 & 0,00 \\
Model & 1 & 777,58 & 8,61 & 0,01 \\
KAM*Model & 2 & 66,49 & 0,74 & 0,48 \\
Galat & 56 & 90,28 & & \\
\hline
\end{tabular}

Tabel 5 hasil pengujian Anava dua jalan sel tidak sama, untuk faktor baris, yaitu kategori KAM, memiliki nilai $\mathrm{F}$ sebesar 268,74 dengan nilai signifikansi sebesar 0,00. Nilai signifikansi tersebut kurang dari $\alpha=0,05$ sehingga dapat disimpulkan bahwa terdapat perbedaan signifikan kemampuan pemecahan masalah matematis antara siswa dengan KAM tinggi, KAM sedang, dan KAM rendah. Faktor kolom, yaitu model pembelajaran, memiliki nilai F sebesar 14,15 dengan nilai signifikansi 0,00 . Nilai signifikansi 0,005 kurang dari $\alpha=0,05$ sehingga disimpulkan terdapat perbedaan signifikan kemampuan pemecahan masalah matematis siswa yang menggunakan model pembelajaran berbasis masalah dengan menulis matematika (kelompok eksperimen) dan siswa yang menggunakan model pembelajaran berbasis masalah saja (kelompok kontrol). Sedangkan untuk interaksi antara KAM dan model pembelajaran menunjukkan nilai $F$ sebesar 5,42 dengan nilai signifikansi 0,01 kurang dari $\alpha=0,05$ sehingga disimpulkan terdapat interaksi antara KAM dan kelompok.

Hasil pengujian statistik untuk kategori KAM menunjukkan terdapat perbedaan kemampuan pemecahan masalah, sehingga dilakukan uji lanjut menggunakan uji Tukey yang hasilnya dapat dilihat pada Tabel 6 .

\begin{tabular}{llcc}
\multicolumn{4}{c}{ Tabel 6. Uji Komparasi Ganda Faktor KAM } \\
\hline \multirow{2}{*}{ KAM (I) } & \multirow{2}{*}{ KAM (J) } & $\begin{array}{c}\text { Selisih Rerata } \\
(\mathrm{I}-\mathrm{J})\end{array}$ & Sig. \\
\hline \multirow{2}{*}{ Tinggi } & Sedang & 2,35 & 0,75 \\
& Rendah & 14,18 & 0,00 \\
\multirow{2}{*}{ Sedang } & Tinggi & $-2,35$ & 0,75 \\
& Rendah & 11,83 & 0,00 \\
\multirow{2}{*}{ Rendah } & Tinggi & $-14,18$ & 0,00 \\
& Sedang & $-11,83$ & 0,00 \\
\hline
\end{tabular}

Berdasarkan Tabel 6, nilai signifikansi antara siswa dengan KAM tinggi dan siswa dengan KAM sedang adalah 0,75. Nilai signifikansi tersebut lebih dari taraf signifikansi 0,05 , sehingga kemampuan pemecahan masalah matematis antara siswa dengan KAM tinggi dan siswa dengan KAM sedang menunjukkan tidak adanya perbedaan signifikan. Nilai signifikansi antara siswa dengan KAM tinggi dan siswa dengan KAM rendah adalah 0,00. Nilai signifikansi tersebut kurang dari taraf signifikansi 0,05 , sehingga kemampuan pemecahan masalah matematis menunjukkan adanya perbedaan kemampuan pemecahan masalah matematis yang signifikan. Nilai signifikansi antara siswa dengan KAM sedang dan siswa dengan KAM rendah adalah 0,00 kurang dari taraf signifikansi 0,05 , sehingga kemampuan pemecahan masalah matematis menunjukkan adanya perbedaan kemampuan pemecahan masalah matematis yang signifikan. 
Hasil uji komparasi ganda pada Tabel 6 menunjukkan adanya perbedaan kemampuan pemecahahn masalah yang signifikan antara siswa dengan KAM tinggi dengan siswa KAM rendah dan siswa dengan KAM sedang dengan siswa KAM rendah. Dikarenakan adanya perbedaan kemampuan pemecahan masalah antar siswa berdasarkan KAM, nilai rata-rata marginal pada Tabel 2 menunjukkan bahwa kemampuan pemecahan masalah matematis siswa KAM tinggi lebih baik daripada siswa dengan KAM rendah dan kemampuan siswa dengan KAM sed ang lebih baik daripada siswa KAM rendah.

Hasil pengujian statistika untuk model pembelajaran yang diberikan, menunjukkan adanya perbedaan kemampuan pemecahan masalah antara kelompok eksperimen dan kelompok kontrol. Perbandingkan kemampuan pemecahan masalah matematis dilakukan dengan melihat rata-rata marginal Tabel 2 tanpaharus melakukan uji lanjut. Hal ini dikarenakan faktor kolom hanya terdiri dari dua nilai sebagaimana diungkapkan oleh Budiyono (2016). Rata-rata marginal kelompok eksperimen lebih besar daripada kelompok kontrol untuk semua kategori KAM, sehingga kemampuan pemecahan masalah matematis siswa kelompok eksperimen lebih baik daripada siswa kelompok kontrol. Perlakuan melalui model pembelajaran yang diberikan pada kelompok eksperimen berdampak positif terhadap kemampuan pemecahan masalah. Robinson (Idris, 2009) menyatakan bahwa menulis matematika dapat memberikan pengaruh positif kemampuan pemecahan masalah. Dalam menulis matematika, siswa membangun ide dan konsep yang selanjutnya setiap ide dan konsep tersebut diuraikan melalui langkah operasional (Skemp dalam Idris, 2009). Idris (2009) menjelaskan lebih lanjut bahwa dengan adanya aktivitas tersebut, siswa akan berpikir lebih dalam sehingga akan terbentuk struktur mental untuk memahami permasalahan matematika atau materi matematika.

Dalam proses pemecahan masalah, siswa diberikan kebebasan untuk mengemukakan konsep melalui menulis matematika. Konsep-konsep tersebut digunakan sebagai refleksi ketika memecahkan masalah. Idris (2009) menjelaskan bahwa dengan adanya bantuan menulis matematika, proses pemecahan masalah menjadi lebih bermakna karena tumbuhnya proses kreatif seperti adanya alternatif metode pemecahan masalah dan adanya eksplorasi. Suhaimi et al. (2017) menjelaskan bahwa melalui menulis matematika menjadikan siswa menjadi reflektif terhadap proses pembelajaran. Artinya, pengetahuan mereka sebelumnya dapat digunakan dengan baik dalam proses pemecahan masalah.

Pengujian terhadap interaksi antara KAM dan model pembelajaran menunjukkan tidak adanya interaksi antar keduanya.

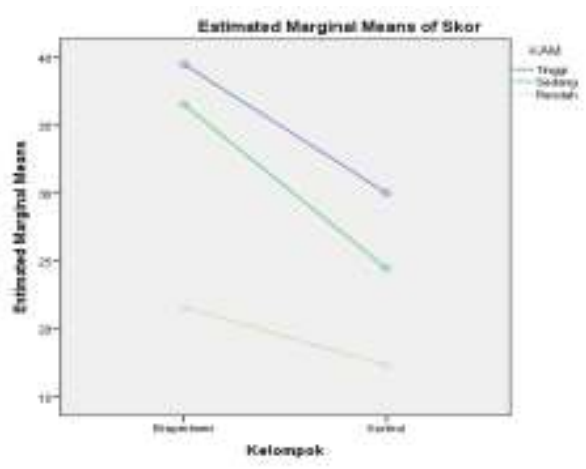

Gambar 1. Profil Efek KAM 
Berdasarkan Gambar 1, dapat dilihat bahwa tidak terdapat perpotongan antara profil dari KAM tinggi, sedang, dan rendah. Rata-rata siswa KAM tinggi, baik pada kelompok eksperimen dan kontrol, selalu lebih tinggi daripada siswa KAM sedang dan rendah. Hal serupa juga untuk nilai rata-rata siswa KAM sedang selalu lebih tinggi daripada siswa KAM rendah untuk kedua kelompok. Kondisi demikian sejalan dengan pendapat Husniah, et al. (Wahyuningtyas et al., 2020) yang menyatakan bahwa kemampuan pemecahan masalah merupakan kemampuan yang melibatkan pemikiran tingkat tinggi. Sebagaimana diungkapkan oleh Vitasari dan Trisniawati (Wahyuningtyas et al., 2020) bahwa individu dengan kemampuan pemecahan masalah yang baik dapat menemukan solusi yang tepat, sehingga siswa harus mengetahui prosedur dan strateginya. Ini menunjukkan bahwa kemampuan awal siswa memberikan dampak secara langsung atau tidak langsung terhadap kemampuan pemecahan masalah untuk dua model pembelajaran yang diberikan. Hal ini berarti bahwa pada siswa KAM tinggi, model pembelajaran berbasis masalah dengan menulis matematika sama efektifnya dengan model pembelajaran berbasis masalah tanpa menulis matematika. Demikian pula pada siswa KAM sedang dan rendah, model pembelajaran berbasis masalah dengan menulis matematika sama efektifnya dengan model pembelajaran berbasis masalah tanpa menulis matematika.

\section{PENUTUP}

Berdasarkan hasil analisis, disimpulkan bahwa kemampuan pemecahan masalah matematis siswa yang menggunakan model pembelajaran berbasis masalah dengan menulis matematika lebih baik daripada siswa yang hanya menggunakan model pembelajaran berbasis masalah secara umum maupun ditinjau dari masing-masing kategori KAM tinggi, sedang, dan rendah. Ditinjau dari KAM, kelompok siswa dengan KAM tinggi dan siswa dengan KAM sedang memiliki kemampuan pemecahan masalah matematis yang tidak berbeda secara signifikan, sedangkan kelompok siswa dengan KAM tinggi dan siswa dengan KAM sedang memiliki kemampuan pemecahan masalah matematis yang lebih baik daripada kemampuan pemecahan masalah siswa dengan KAM rendah.

\section{DAFTAR PUSTAKA}

Andriatna, R. (2015). Meningkatkan Kemampuan Pemecahan Masalah Matematis Siswa SMA melalui Menulis Matematika dalam Pembelajaran Berbasis Masalah. Prosiding Seminar Matematika Dan Pendidikan Matematika Jurusan Pendidikan Matematika Universitas Negeri Yogyakarta.

Barrows, H., \& Kelson, A. C. (1995). Problem-Based Learning in Secondary Education and the Problem-Based Learning Institute. Problem-Based Learning Institute, Springheld.

Budiyono. (2016). Statistika untuk Penelitian (2nd ed.). Surakarta: UNS Pres. 
Dahar, R. W. (2006). Teori-teori Belajar dan Pembelajaran. Bandung: PT. Gelora Aksara Pratama.

Foshay, R., \& Kirkley, J. (1998). Principles for Teaching Problem Solving. Bloomington, $\mathrm{MN}$ : PLATO Learning, Inc.

Gick, M. L., \& Holyoak, K. J. (1980). Analogical Problem Solving. Cognitive Psychology, 12(3), 306355.

Hmelo-Silver, C. E. (2004). ProblemBased Learning: What and How Do Students Learn? Educational Psychology Review, 16(3), 235266.

Hmelo-Silver, C. E., \& Ferrari, M. (1997). The Problem-Based Learning Tutorial: Cultivating Higher-Order Thingking Skills. J.Educ.Gifted, 20, 401-422.

Hudojo, H. (2003). Pengembangan Kurikulum dan Pembelajaran. Bandung: Alfabeta.

Idris, N. (2009). Enhancing Student' Understanding in Calculus through Writing. International Electronic Journal of Mathematics Education, 4(1), 36-55.

Kolodner, J. L., Hmelo-Silver, C. E., \& Narayanan, N. H. (1996). Problem-Based Learning Meets Case-Based Reasoning. In D. C. Edelson \& E. A. Domeshek (Eds.), Proceedings of ICLS 96 (pp. 188195). AACE, Charlottesville, VA.

Marhami. (2016). Pengaruh Strategi Pembelajaran Konflik Kognitif terhadap Kemampuan Pemahaman Relasional dan Komunikasi Matematis serta SelfRegulation Siswa SMP. Universitas Pendidikan Indonesia.
Mayer, R. (1983). Thingking, Problem Solving, Cognition. New York: W.H. Freeman and Company.

Meika, I., \& Sujana, A. (2017). Kemampuan Berpikir Kreatif Dan Pemecahan Masalah Matematis Siswa SMA. Jurnal Penelitian Dan Pembelajaran Matematika, 10(2), 8-13. https://doi.org/10.30870/jppm.v10 i2.2025

Mullis, I. V. S., Martin, M. O., Foy, P., \& Arora, A. (2012). TIMSS 2011 International Results in Mathematics. Chestnut Hill, MA : TIMSS \& PIRLS International Study Center, Lynch School of Education, Boston Collage.

NCTM. (2000). Principles and Standards fo School Matematics. Reston, VA : National Council of Teachers of Mathematics.

Nidya, Wulandari, F., \& Jailani. (2015). Indonesian Student's Mathematics Problem Solving Skill in PISA and TIMSS. Proceeding of Internaational Conference on Research, Implementation, and Education of Mathematics and Sciences 2015 (ICRIEMS 2015).

Pinter, K. (2012). On Teaching Mathematical Problem-Solving and Problem Posing. University of Szeged.

Ruseffendi, E. T. (2010). Dasar-dasar Penelitian Pendidikan dan Bidang Non Eksakta Lainnya. Bandung: Tarsito.

Saragih, S., Napitupulu, E. E., \& Fauzi, A. (2017). Developing Learning Model Based on Local Culture and Instrument for Mathematical Higher Order Thingking Ability. International Education Studies, 10(6), 104-122. 
Savery, J. R. (2006). Overview of Problem-based Learning: Definitions and Distinctions. Interdisciplinary Journal of Problem-Based Learning, 1(1), 920.

https://doi.org/https://doi.org/10.7 771/1541-5015.1002

Schoenfeld, A. H. (1980). Teaching Problem-Solving Skills. The American Mathematical Monthly, 87(10), 794-805.

Schoenfeld, A. H. (1987). Polya, Problem Solving, and Education. Mathematics Magazine, 60(5), 283-291.

Simamora, R. E., Saragih, S., \& Hasratuddin. (2019). Improving Students' Mathematical Problem Solving Ability and Self-Efficacy through Guided Discovery Learning in Local Culture Context. International Electronic Journal of Mathematics Education, 14(1), 61-72.

Suhaimi, Z., Shahrill, M., Abbas, N. H., Tengah, K. A., Roslan, R., \& Yusof, N. (2017). Exploring the Use of Journal Writing in Mathematics Classroom. International Journal on Emerging Mathematics Education (IJEME), 1(1), 41-52. https://doi.org/http://dx.doi.org/10 .12928/ijeme.v1i1.5683
Trianto. (2009). Mendesain Model Pembelajaran Inovatif-Progresif. Jakarta: Kencana Prenada Media Group.

Turmudi. (2012). Teachers' Perception Toward Mathematics Teaching Innovation in Indonesia Junior High School: An Exploratory Factor Analysis. Journal of Mathematics Education, 5(1), 97120.

Wahyuningtyas, P. S., Setiani, Y., \& Khaerunnisa, E. (2020). Pengaruh Model CORE dengan Pendekatan Open Ended terhadap Kemampuan Pemecahan Masalah Matematis Siswa SMP. Journal of Medives : Journal of Mathematics Education IKIP Veteran Semarang, 4(1), 8196. https://doi.org/https://doi.org/10.3 1331/medivesveteran.v4i1.979 